УДК 347.97/.99

DOI https://doi.org/10.32849/2663-5313/2019.9.47

\title{
Олена Копитова,
}

канд. юрид. наук,

суддя Київського апелячійного господарського суду, старший науковий співробітник відділу наукової діяльності та захисту права інтелектуальної власності

Начіональної академії внутрішніх справ

\section{СУЧАСНЕ НОРМАТИВНЕ РОЗУМІННЯ ПРАВА ЯК ТЕОРЕТИЧНА ОСНОВА ФОРМУВАННЯ МИСЛЕННЯ СУДДІВ}

Стаття присвячена дослідженню проблеми сучасного нормативного розуміння права як теоретичної основи формування мислення суддів. З'ясовано роль судового праворозуміння у формуванні практичного та наукового мислення суддів, у механізмі удосконалення єдності судової практики. Досліджено механізм того, як правовий ідеал може трансформуватися у діюче позитивне (сучасне нормативне) праворозуміння. Розкрито течї (типи) праворозуміння та зроблено висновок, що найбільи оптимальними для формування мислення суддів є інтегративний та синергетичний типи праворозуміння. Доведено, що сучасне нормативне розуміння права як теоретична основа мислення суддів базується не тільки на взаємодії природного та юридико-позитивістського, а й на інших типах праворозуміння, які у своій сукупності та взаємодї̈ формують цілісне уявлення про право, праворозуміння та ефективне судове правозастосування, яким завершується будь-який правовий конфлікт як результат некоректного, суб'єктивного розуміння учасниками суспільних відносин власних прав та обов'язків. Додатково торкнемося типів правозастосування, що допоможуть стати належним базисом для подальших підрозділів нашого дослідження. Зроблено висновок, що інтегративний тип праворозуміння поєднує усе иінне у природно-правовому та юридико-позитивістському типах праворозуміння. Його особливість полягає у тому, що всі ознаки розуміння права є істотними й необхідними, $i$ ией підхід полягає у спробі поєднати на якісно новому рівні різні кониепиії розуміння права, у зв'язку з чим створюється нова школа права, яка б відповідала вимогам сучасного періоду, вимогам конкретної епохи. Згідно з інтегративним підходом до розуміння права, усі його ознаки є істотними й необхідними. Синергетичний підхід характеризується тим, що враховує випадковість як високу ймовірність впливу на суспільні системи, в тому числі правові, на їх трансформацію. У ивому типі праворозуміння правозастосувач, а особливо суддя, виявляе принципово нові знання про право та виходить на чілком новий образ права через нелінійний підхід до розуміння права.

Ключові слова: нормативне праворозуміння, інтегративне розуміння, синергетичний тип праворозуміння, природно-правовий тип праворозуміння, позитивістське праворозуміння, судове правозастосування.

Постановка проблеми. Проблема судового правозастосування є однією 3 найбільш складних для сьогодення, теоретично і практично значущих з огляду на тотальні реформи в усіх сферах життєдіяльності держави [15, с. 42]. На жаль, слід констатувати, що глибина і послідовність реформ, що проводяться державою у сфері судової влади, не $є$ ефективними, а відзначаються радше перманентною стабільністю реформ заради реформ. Зокрема, останне реформування в судовій системі на конституційному рівні, незважаючи на закладення істотних змін інституційного рівня щодо підстав і порядку здійснення правосуддя судами і початок нової епохи судового правозастосування, знову опинилося в ситуації потреби рефор- мування у зв'язку з новим політичним курсом держави. Повною мірою це може стосуватися і порядку розгляду судових справ судами, центральною стадію якого є правозастосування як центральний компонент порядку здійснення правосуддя судами, що грунтується і випливає із розуміння суддею нормативної основи та характеру спірних відносин справи.

Теоретичне дослідження проблем судового праворозуміння й правозастосування постійно перебувало і перебуває у колі уваги правової науки, зокрема таких провідних вчених-правників: М. Г. Александрова, С. С. Алексєєва, Є. Г. Бобрєшова, С. В. Бобровник, В. М. Горшеньова, С. Д. Гусарєва, М. Д. Гнатюка, О. В. Зайчука, А. М. Колодія, В. В. Лазарєва, М. І. Мату- 
зова, В. С. Нерсесянца, Ю. М. Оборотова, Н. М. Оніщенко, О. В. Петришина, В. М. Протасова, П. М. Рабіновича, М. Б. Рісного, Ю. Г. Ткаченка, В.Н.Шабаліна, С.В.Шевчука,Л.С.Явича та багатьох інших правознавців.

Водночас проблема судового праворозуміння як складника правозастосовної діяльності та правової форми здійснення функцій держави після проведеної конституційної реформи щодо правосуддя [15, с. 42] ще не встигла отримати достатньої наукової розробки з урахуванням досягнень сучасної науково-правової думки та узагальнень судової практики. Йдеться про останні реформи, коли змінена власне концепція судового правозастосування, а саме: найвищому суду системи судоустрою фактично перейшло право офіційного тлумачення закону, в чому, окрім істотних переваг і мобільного впливу на трансформацію спірних відносин, вбачаємо істотні ризики у вигляді підміни судами законодавця.

Тобто вказана новела зумовлюе необхідність переосмислення значення праворозуміння у судовому правозастосуванні з розкриттям його ролі у формуванні практичного та наукового мислення суддів, у механізмі удосконалення єдності судової практики, що і виступатиме метою цієї наукової публікації.

Виклад основного матеріалу. Розпочати слід із наведення слушної позиції О. С. Ткачука, що наріжною проблемою судового правозастосування сьогодні є спірні питання імплементації принципу верховенства права у реальну судову практику $[29$, с. 6$]$. Потреба у всебічному вивченні такої правової категорії зумовлена також значним оновленням, гармонізацією законодавства 3 міжнародними стандартами; змінами в організації та функціонуванні судової влади; розвитком усіх видів судочинства [15, с. 42].

Судове правозастосування органічно пов'язано і перебуває у взаємозалежності 3 проблемою праворозуміння, яка $є$ центральною категорією права. Адже будь-який правозастосувач, а особливо суддя, повинен мати чітке уявлення про право, що є базовим, відправним поняттям правового життя суспільства. Без розуміння права неможливо володіти правильним орієнтиром у правовій дійсності, адже право лежить в основі всіх правових явищ, що існують у суспільстві. Зокрема, питання про правомірне та неправомірне (протизаконне) є квінтесенцією діяльності суду [1, с. 18]. Відомий теоретик права і соціолог Б. О. Кістяківський свого часу ілюстрував перше знайомство 3 наукою про право, яка для нього створювала враження сукупності теорій, які взаємно виключають одна одну [11, с. 42].
Розпочнемо з короткої ілюстрації загального розуміння права у філософському аспекті та трансформації такого ідеалу у реальне життя в конкретні періоди розвитку суспільства. Тобто дослідимо, як правовий ідеал може трансформуватися у діюче позитивне (сучасне нормативне) право.

Враховуючи швидкоплинність суспільних відносин, вимушені констатувати їх постійну нестиковку з наявною правовою регламентацію. Природно, така ситуація викликає правові конфлікти, які трансформуються, як правило, у судові спори, і саме у пошуку компромісу між правовим ідеалом і позитивним нормативним правом у його класичному чи сучасному розумінні щоденно перебуває суддя під час судового правозастосування.

Звернення до надбань теорії права та філософської літератури переконує, що право у філософському розумінні являе собою абстрактний еталон тих правил поведінки, які в ідеалі відповідають рівню розвитку даного конкретного суспільства на конкретному історичному етапі і які ідеально відповідають можливості його найбільш гармонійного розвитку. При цьому зауважимо, що абстрактний правовий ідеал не $€$ синонімом природного права, яке, згідно 3 природно-правовою доктриною, випливає із природи людини, людського розуму, загальних моральних принципів, тому воно є розумним і справедливим, не обмежується межами окремих держав, поширюється на всі часи і народи. Воно є вічним та незмінним, як є вічними і незмінними природа та розум людини [3, с. 43-46, 92-100; 17, с. 34-35, 1, c. 34-35].

На противагу цьому об'єктивне право викликається об'єктивними потребами людей, що проявляються в соціальних відносинах та зв'язках, воно в ідеалі відображає ці потреби, а саме вони, ці потреби, а не «об'єктивне право», впливають на людей (у тому числі на законодавця). Потреби природним чином впливають на трансформацію відносин, люди у своїх відносинах намагаються «вирватися» із формальних норм, певним чином чи повністю застарівших на даний момент.

Однак саме у цьому полягає практична площина праворозуміння й одночасно виникає ряд проблем, адже саме ці формальні норми, нехай вже і відсталі від життя, хоч і заважають прогресу, проте не просто написані на папері, вони мають реальну силу захисту - державну силу, а тому будь-який відступ від цих формальних норм може викликати негативну реакцію держави [1, с. 38-39]. У тому числі ініціювання судо- 
вих процесів, що природно тягне за собою судовий розгляд, в межах якого відбувається судове правозастосування, в якому суддя встановлює компроміс між правовим ідеалом та реаліями дійсності. Тобто точне слідування чинному позитивному праву, цілком можливо, і суперечність «об'єктивному» праву, також може викликати негативну реакцію держави.

Підкреслимо, що останніми роками українське суспільство відчуло й зрозуміло небезпеку «формального» підходу до оцінки діянь того чи іншого суб'єкта стосовно кожного конкретного випадку. Внаслідок цього відбулася переоцінка правозастосувальних ситуацій з позицій аксіологічного (ціннісного) підходу, коли будь-який правозастосувач, а особливо суддя, має порівняти і дослідити співвідношення абстрактного ідеалу i конкретною правозастосувальною ситуацію. У цьому, на наш погляд, і полягає новий підхід до сучасного нормативного розуміння права як теоретичної основи формування мислення суддів.

Розкриємо це більш докладно. Звернення до надбань вітчизняних правників, передусім представників науки теорії права, дає підстави говорити про таке. Актуальність явища праворозуміння та пов’язаність цієї актуальності з існуванням права як такого відзначєа Н. І. Мозоль, яка підкреслює намагання усіх наявних концепцій пояснити, об'єднати, інтегрувати, зокрема, шляхом компромісу, однак вони навряд чи здатні повністю усунути розбіжності [16, с. 37]. Згадана вчена, досліджуючи особливості праворозуміння, робить слушний (в аспекті нашої публікації) висновок про постійну трансформацію та вдосконалення явища праворозуміння в теорії через юридичну практику, а для практиків-фахівців у галузі права - через нові розробки теоретиків права [16, с. 38]. У свою чергу П. Оль наголошує, що теоретичне праворозуміння має на увазі виявлення об'єктивних законів, тих найважливіших зв'язків, які об'єднують і підпорядковують собі всі елементи права як специфічної системи [19, с. 23].

Аналізуючи теоретичні підходи до власне визначення категорії «праворозуміння», слід констатувати, що їх у теорії права існуе чимало. Разом із тим усі визначення не знімають загальної дискусії як щодо поняття праворозуміння, зокрема, в контексті нормативного праворозуміння як сучасного динамічного компонента праворозуміння в широкому розумінні слова, так і щодо питання правозастосування, особливо зважаючи на останні трансформаційні процеси у сфері права.

За Ю. С. Шемшученком, праворозуміння - це «усвідомлення правової дійсності через призму правових теорій, доктрин, концепцій» [31, с. 48-49], спосіб освоєння правової дійсності; цим терміном «позначається не тільки поняття права чи його визначення, а й уся сукупність загальнотеоретичних понять і визначень, що охоплюють правову реальність» $[28$, с. 120$]$. «Різні підходи, аспекти, точки зору щодо поняття права та окремих форм його впливу» - це «зміст праворозуміння» [19, с. $62 ; 21$, с. 19$]$.

Примітним видається погляд П. М. Рабіновича на значення терміно-поняття «праворозуміння», а саме: це відображення в людській свідомості за посередництвом поняття, що позначається терміном «право» (або будь-яким іншим однозначним з ним словом чи символом), того явища, яке оцінюється певним суб'єктом як корисне для задоволення потреб його існування та розвитку і забезпечується обов'язками інших суб'єктів [23, с. 153]. Погоджуючись із викладеною позицією, додатково зауважимо, що поділяємо думку вітчизняного вченоготеоретика в частині недосконалості дослідження праворозуміння через пізнання права. П. М. Рабінович підкреслює, що вислів про те, що праворозуміння - це пізнання (розуміння) права, вочевидь, є хибним 3 погляду логіки: адже перш ніж пізнавати, усвідомлювати право, досліднику попередньо саме і потрібно зрозуміти, а щ ж являє собою, на його думку, те явище, яке він відображає і позначає термінопоняттям «право». Але такі знання й становитимуть не що інше, як праворозуміння, принаймні його серцевину, його концептуальний стрижень [23, с. 154].

Слід погодитись із думкою С. В. Бобровник, що праворозуміння - це система знань концептуального характеру про найбільш загальні закономірності становлення та функціонування права, його сутність, призначення та місце в суспільстві, які визнані логічно та об'єктивно істинними і включеними до складу правознавства як науки. Праворозуміння має дискусійний характер, що відтворює специфіку функціонування форм суспільної свідомості в сучасному суспільстві та їхній вплив на формування соціальної реальності. Воно націлене на повне осмислення можливості включення гуманітарних понять у сферу соціальних практик. $€$ головним чинником пояснення колізій та спорів. Воно відображає різні підходи до права, погляди та розвиток правових явищ і оцінку їхньої відповідності в правовому порядку [4, с. 88, 92]. Також праворозуміння розглядається як процес та результат розумової діяльності людини, спрямованої на пізнання права, його сприйняття (оцінку) і ставлення до нього як до цілісного соціального явища [13, с. 58]. 
Варто погодитися з думкою С. С. Алексєєва, що «праворозуміння є певною, насамперед, науковою категорією, що відображає процес і результат цілеспрямованої розумової діяльності людини, що містить пізнання права, його оцінку та ставлення до нього як до цілісного соціального явища» [2, с. 169]. Аналогічного висновку дійшов також М. С. Кельман [10, с. 266]. В. І. Гойманом пропонується модель праворозуміння, відповідно за якої правові гарантії повинні знаходити своє відображення у правовій активності. Даний підхід дає можливість повніше врахувати природно-правове походження права, його генетичний зв'язок із суспільним суб'єктом - людською особистістю. Правовим може визнаватися юридично належне, котре породжене та апробоване суспільною практикою, пов'язане з пріоритетами, цінностями особистості, слугує загальному інтересу, стимулює ініціативність, захищає від сваволі та насильства [6, с. 845].

Аналізуючи проблеми сучасного нормативного розуміння права, неможливо не торкнутися в цілому боротьби течій (типів) праворозуміння. Під типом праворозуміння загалом розуміють смислову модель права, що визначається його джерелами чи уявленням про предмет теорії права [18, с. 6].

Зауважимо, що у нашому дослідженні не ставимо за мету з'ясування всіх наукових шкіл праворозуміння, тому торкнемося тільки тих, які, на наш погляд, можуть стати певною відправною точкою (базисом) для формування теоретичної основи мислення суддів: природно-правової, позитивістської, соціологічної та інтегративної [9, с. 3; 7, с. 264-296; 26 , с. $141-162 ; 7$, с. $89-91 ; 25$, с. $9-16$ ]. Коротко зупинимося на кожній із них:

1) аксіологічний (ідеологічний) (праці Аристотеля, Цицерона, Святого Августина, Томи Аквінського, Г. Гроція, С. Пуфендорфа, Дж. Локка, I. Канта та ін.) [26, с. 141]: вихідна форма буття права - громадська свідомість; право - не тексти закону, а система ідей або понять про загальнообов'язкові норми, права, обов'язки, заборони, природні умови іх виникнення та реалізації, порядок і форми захисту, які є в громадській свідомості й орієнтовані на моральні цінності. У разі такого підходу право і закон розмежовуються, пріоритет надається праву як нормативно закріпленій справедливості, а закон розглядається як його форма, покликана відповідати праву як його змісту [16, с. 38];

2) юридико-позитивістський (нормативний) (Т. Гоббс, Дж. Остин, м'які позитивісти Г. Харт, Дж. Коулмен та ін.) [26, с. 143]: вихідна форма буття права - норма права, право - норми, викладені в законах та інших нормативних актах. У такому підході відбувається ототожнення права й закону. Водночас нормативне праворозуміння орієнтує на такі властивості права, як формальна визначеність, точність, однозначність правового регулювання [16, с. 38];

3) соціологічний: вихідна форма буття права (Є. Ерліх, Ж. Гурвіч, Р. Паунд, Б. Кордозо, К. Ллевеллін, Дж. Френк та ін.) [26, с. 143] - правовідносини; право - порядок суспільних відносин, який виявляється в діях і поведінці людей. За такого підходу правом визнається його функціонування, реалізація, його «дія» в житті - у сформованих і таких, що формуються, суспільних відносинах, а не його створення правотворчими органами у формі закону та інших нормативно-правових актів. Прихильники цього підходу ототожнювали самостійні процеси правотворчості й застосування права, тоді як умовою дотримання та забезпечення режиму законності може бути діяльність правозастосувача в межах, установлених законом [16, с. 38]. 3 цього приводу M.I. Козюбра слушно підкреслює, що прихильники соціологічного типу праворозуміння переносять акцент 3 абстрактних ідеалів і нормативно-правових текстів в площину конкретного, динамічного функціонування права, його дії в реальному житті, насамперед у правовідносинах та юридичних рішеннях, без чого ідеали і юридичні тексти перетворюються на декларації, які не мають прямого відношення до права. Останні два аспекти права можна віднести до реального або фактичного виміру права [8, с. 39].

H. I. Мозоль, грунтуючись на позиціях інших вчених [12, с. $16 ; 24$, с. $6 ; 10$, с. 115 ; 14, с. 88], коротко підсумовує, що природноправовий тип праворозуміння акцентує увагу на праві як духовному феномені, на ідеалах справедливості, індивідуальної свободи, рівності, суспільної злагоди та інших цінностях, без яких право неможливе. Юридико-позитивістський тип праворозуміння, констатує дослідниця, зосереджує увагу на нормативно-інституціональних аспектах права, без яких такі його вимоги, як визначеність, передбачуваність, упорядкованість, стабільність тощо, недосяжні [16, с. 38]. Соціологічний рух, на їі думку, зосереджує увагу не на логічному аналізі норм права, не на встановленні зв'язку права і моралі, а на дослідженні фактичних правовідносин, з'ясуванні різноманітних соціологічних чинників, що впливають на застосування норм права до конкретних життєвих випадків і в такий спосіб визначають справжнє обличчя права [26, с. 143]. 
Стосовно поєднання природно-правового та юридико-позитивістського типів праворозуміння слушними є висновки М. І. Козюбри [8, с. 39] з приводу дуальності права, тобто поєднання у ньому двох засад, які не зводяться одна до одної. У цьому контексті вчений наводить принаймні три застереження. Перш за все, за М. І. Козюброю, дуальність права полягає саме в синтезі у ньому ідеального і реального вимірів, а не в поєднанні світоглядів природного права, зумовленого природним станом людини, і позитивного права, тобто волевиявленого державою, як це інколи трапляється в літературі. Намагання такого поєднання призводить до світоглядної еклектики [8, с. 39]. Другим застереженням, на думку вченого, є те, що певна дуальність права спостерігається не тільки на рівні стосунків ідеального і реального у ньому, а й на рівні реального, фактичного існування права. Адже авторитетно встановлені норми, навіть якщо вони узгоджуються з ідеальним виміром права - ідеалами справедливості, свободи, рівності, самі по собі ще не право, а лише один із щаблів на шляху його актуалізації. Без їх відтворення в поведінці (діях) людей, зокрема в правовідносинах і юридичних рішеннях, вони залишаються фікцією. 3 іншого боку, правовідносини і юридичні рішення ніколи не «виводяться» безпосередньо $з$ норм закону - абстрагуючись від повноти конкретного, він схематизує реальність. Якщо закон є всезагальною нормою для багатьох можливих випадків, то «право», навпаки, вирішує дійсну ситуацію тут і зараз. Право, на відміну від закону, завжди конкретне [8, с. 39]. I по-третє, М. I. Козюбра підкреслює, що дуальність права не обмежується поєднанням у ньому ідеального і реального, вона знаходить свій прояв також в інших формах - синтезі абстрактного і конкретного, теоретичного і практичного, раціонального та ірраціонального тощо. Усі вони ще раз засвідчують надзвичайну складність і багатобарвність права як явища [8, с. 40].

Останнє застереження $€$ надзвичайно важливим у контексті нашого дослідження, оскільки розглядається проблема сутності сучасного нормативного розуміння права, яке має стати теоретичною основою формування мислення суддів.

На наш погляд, сучасне нормативне розуміння права базується не тільки на взаємодії природного та юридико-позитивістського, а й на інших типах праворозуміння, які у своїй сукупності та взаємодії формують цілісне уявлення про право, праворозуміння та ефективне правозастосування. Це стосується насамперед судового правозастосування, яким завершується будь-який правовий конфлікт як результат некоректного, суб'єктивного розуміння учасниками суспільних відносин власних прав та обов'язків. Додатково торкнемося типів правозастосування, що допоможуть стати належним базисом для подальших підрозділів нашого дослідження.

Інтегративний тип праворозуміння поєднує усе цінне у природно-правовому та юридико-позитвістському типах праворозуміння. Особливість цього підходу полягає у спробі поєднати на якісно новому рівні різні концепції розуміння права, у зв'язку 3 чим створюється нова школа права, яка б відповідала вимогам сучасного періоду, вимогам конкретної епохи. У цьому контексті слушним є погляд О. В. Геселева, який вважає, що найбільш оптимальним є такий підхід до праворозуміння, що полягає у створенні цілісної, інтегративної концепції права, яка відображає реалії сучасної соціокультурної цивілізаційної ситуації й об'єднує ідеї основних напрямів та підходів до розуміння права. При цьому для опису різноманіття проявів права знаходиться, тим не менш, головний критерій, на якому грунтується право та який перетворює видиму соціокультурну розмаїтість права в усвідомлювану, пізнавану логіко-значеннєву єдність [5, с. 97]. Згідно з інтегративним підходом до розуміння права, усі його ознаки є істотними й необхідними. Характеризуючи право, слід аналізувати його зміст і форму. Д. Холл прагне створити єдине уявлення про право шляхом синтезу правових норм, правових процесів і моральних цінностей [16, с. 38].

Ще один підхід, що становить науковий інтерес як у межах цього підрозділу, так і для наукової праці в цілому, - синергетичний підхід, який «на відміну від класичних уявлень про однолінійність процесів розвитку матерії, властивих механістичному світогляду недавнього минулого, відповідно до якого всі системи, зокрема й правові, діють на основі об'єктивної необхідності науково пізнаних законів» [16, с. 39], характеризується тим, що враховує випадковість (виділено нами - О.К.) як високу ймовірність впливу на суспільні системи, в тому числі правові, на їх трансформацію. У цьому типі праворозуміння правозастосувач, а особливо суддя, виявляє принципово нові знання про право та виходить на цілком новий образ права через нелінійний підхід до розуміння права [30, с. 8].

Отже, ілюстрація наведених підходів свідчить, що загалом проблема праворозуміння перебуває у взаємозв'язку із правозастосуванням. Особливо відчутно це у здійсненні правосуддя судами шляхом правозастосувальної діяльності. 


\section{Висновки}

Підсумовуючи викладене, зазначимо, що сучасне нормативне розуміння права як теоретична основа мислення суддів базується не тільки на взаємодії природного та юридико-позитивістського, а й на інших типах праворозуміння, які у своїй сукупності та взаємодії формують цілісне уявлення про право, праворозуміння та ефективне судове правозастосування, яким завершується будь-який правовий конфлікт як результат некоректного, суб'єктивного розуміння учасниками суспільних відносин власних прав та обов'язків. Щодо типів правозастосування зазначимо таке.

Інтегративний тип праворозуміння поєднує усе цінне у природно-правовому та юридико-позитивістському типах праворозуміння. Його особливість полягає у тому, що усі ознаки розуміння права є істотними й необхідними, і цей підхід полягає у спробі поєднати на якісно новому рівні різні концепції розуміння права, у зв язку з чим створюється нова школа права, яка б відповідала вимогам сучасного періоду, вимогам конкретної епохи. Згідно з інтегративним підходом до розуміння права, усі його ознаки є істотними й необхідними. Синергетичний підхід характеризується тим, що враховує випадковість як високу ймовірність впливу на суспільні системи, в тому числі правові, на їх трансформацію. У цьому типі праворозуміння правозастосувач, а особливо суддя, виявляє принципово нові знання про право та виходить на цілком новий образ права через нелінійний підхід до розуміння права.

\section{Список використаних джерел:}

1. Аверин А,В. Судебное правоприменение и формирование научно-правового сознания судей : дисс. ... докт. юрид. наук. Саратов. 2004. 336 с.

2. Алексеев С. С. Теория права. Москва : БЕК, 1994. $224 \mathrm{c}$.

3. Байтин М.И. Сущность права (Современное нормативное правопонимание на грани двух веков) : монография. Саратов: СГАП, 2001. 416 с.

4. Бобровник С. В. Сучасне правопізнання: теоретичні проблеми та роль у подоланні колізій. Правова держава. 2005. Вип. 16. С. 87-92.

5. Геселев О. В. Інтегративне праворозуміння як складова сучасної постмодернової правової культури: сутність та актуальне значення. Актуальні проблеми держави і права. 2009. С. 96-103.

6. Гойман В. Праворозуміння (точка зору). Міжнародна полічейська енииклопедія : у 10 т. / відп. ред. Ю. І. Римаренко, Я. Ю. Кондратьєв, В. Я. Тацій, Ю.С. Шемшученко. Т. 1. Київ : Концерн «Видавничий Дім «Ін Юре», 2003. С. 845.

7. Загальна теорія держави і права : підручник для студентів юридичних вищих навчальних закладів / М. В. Цвік, О. В. Петришин, Л. В. Авраменко та ін.; за ред. д-ра юрид. наук, проф., акад. АПрН України М. В. Цвіка, д-ра юрид. наук, проф., акад. АПрН України О. В. Петришина. Харків: Право, 2009. 584 с.

8. Загальна теорія права : підручник / за заг. ред. М.І. Козюбри. Київ : Ваіте, 2016. 392 с.

9. Заєць А. Світоглядні основи праворозуміння. Вісник Академії правових наук України. 1997. № 2. C. 3-12.

10. Кельман М. С., Мурашин О. Г., Хома Н. М. Загальна теорія держави та права : підручник. 3-тє вид. Львів : Новий світ, 2007. 584 с.

11. Кістяківський Б. О. Вибране. Бібліотека часопису «Філософська і соціологічна думка». Серія «Українські мислителі». Київ, 1996. 371 с.

12. Козюбра М. Праворозуміння: поняття, типи та рівні. Право Украӥни. 2010. № 4. С. 10-22.

13. Загальна теорія держави і права / Колодій А. М., Копєйчиков В. В., Лисенков С. Л., Пастухов В. П., Тихомиров О. Д. ; за ред. проф. В. В. Копєйчикова. Київ : Юрінком Інтер, 1997. 320 с.

14. Лившиц Р. 3. Теория права : учебник. Москва, 2001. 200 с.

15. Мельничук С.М. Поняття судового правозастосування як правової форми здійснення функцій держави. Право і Безпека. 2015. 3(58). С. 42-46.

16. Мозоль Н. І. Сучасні концепції праворозуміння: поняття, характеристика та особливості. Науковий вісник Національної академії внутрішніх справ. 2013. № 1. С. 36-41. URL: http:// nbuv.gov.ua/UJRN/Nvknuvs 2013107 (дата звернення: 10.08.2019).

17. Нерсесянц В.С. Философия права : учебник для вузов. Москва: Норма, 2005. 256 с.

18. Овчинников А.М. Правопонимание и его классификация: основные подходы. Юрист-правовед. 2015. № 1 (68). С. 5-9.

19. Олійник А.Ю., Гусарєв С.Д., Слюсаренко О.Л. Теорія держави і права : навчальний посібник. Київ : Юрінком Інтер, 2001. 176 с.

20. Оль П. А. Правопонимание : от плюрализма к двуединству. СПб., 2006. 243 с.

21. Правосуддя: філософське та теоретичне осмислення : колективна монографія / А. М. Бернюков, В. С. Бігун, Ю. П. Лобода, Б. В. Малишев, С. П. Погребняк, С. П. Рабінович, В. С. Смородинський, О. В. Стовба ; відп. ред. В. С. Бігун. Київ, 2009. $316 \mathrm{c}$.

22. Принцип верховенства права: проблеми теорії та практики : монографія : у 2 кн. / за заг. ред. Ю. С. Шемшученка; відп. ред. Н. М. Оніщенко. Київ, 2008. Кн. 1. Верховенство права як принцип правової системи : проблеми теорії. 2008. C. 81-102.

23. Рабінович П. Деякі сучасні концепції права в Росії та Україні (у світлі потребового праворозуміння). Філософія права і загальна теорія права. 2013. № 1. C. $150-168$.

24. Рабінович П. Загальносоціальна («природна») правова система: поняття і структура. Вісник Академії правових наук України. 2008. № 4 (55). C. 3-12. 
25. Рабінович П. М. Основи загальної теорії права та держави : навчальний посібник. 10-е вид., доповнене. Львів: Край, 2008. 224 с.

26. Теорія держави і права : підручник / Петришин О. В., Погребняк С. П. , Смородинський В. С. та ін. ; за ред. О. В. Петришина. Харків : Право, 2015. 368 c

27. Скакун О. Ф., Подберезский Н. К. Теория права и государства : учебник. Харьков, 1997. $654 \mathrm{c}$.
28. Теорія держави і права / за заг. ред. С. Л. Лисенкова, В. В. Копєйчикова. Київ, 2002. 360 с.

29. Ткачук О.С. Реалізація судової влади у цивільному судочинстві України: структурнофункціональний аспект : автореф. дис. ... канд. юрид. наук: 12.00.03. Харків, 2019. 20 с.

30. Честнов И. Л. Правопонимание в эпоху постмодерна. Правоведение. 2002. № 2 (241). С. 4-16.

31. Шемшученко Ю. С. Праворозуміння. Юридична енциклопедія. Київ, 2003. Т. 5. С. 48-49.

The article is devoted to the study of the problem of modern normative understanding of law as a theoretical basis for the formation of the thinking of judges. The role of judicial law understanding in shaping the practical and scientific thinking of judges in the mechanism of improving the unity of judicial practice has been clarified. The mechanism is investigated as a legal ideal can be transformed into the current positive (modern regulatory) legal thinking. The trends (types) of legal understanding are revealed and the conclusion is drawn that the most optimal for the formation of the judges' thinking is the integrative and synergistic types of legal understanding. It is proved that the modern normative understanding of law as a theoretical basis for the thinking of judges is based not only on the interaction of natural and legal-positivist, but also on other types of legal thinking, which in their totality and interaction form a holistic view of law, legal thinking and effective judicial enforcement. any legal conflict ends as a result of incorrect, subjective understanding by the participants of public relations of their own rights and obligations. In addition, we will address the following types of enforcement that will help to provide a proper basis for further units in our study. It is concluded that the Integrative type of legal thinking combines all the valuable in natural law and legal-positivist types of legal thinking. Its peculiarity is that all the features of understanding the law are essential and necessary, and this approach is to try to integrate different concepts of understanding of law at a new level, thus creating a new school of law that would meet the requirements of the modern period, the requirements of a particular era. According to an integrative approach to understanding the law, all its features are essential and necessary. The synergistic approach is characterized by the fact that it considers chance as a high likelihood of impact on social systems, including legal systems, on their transformation. In this type of legal reasoning, the law enforcer, and especially the judge, discovers a fundamentally new knowledge of law and takes on a whole new image of law through a non-linear approach to understanding law.

Key words: regulatory legal understanding, integrative understanding, synergistic type of legal understanding, natural legal type of legal understanding, positivistic legal thinking, judicial enforcement. 